\title{
Day-to-day variation in milk yield and milk composition at the udder-quarter level
}

\author{
L. Forsbäck, ${ }^{* 1}$ H. Lindmark-Månsson,† A. Andrén,ł M. Åkerstedt, ${ }^{*}$ L. Andrée, ${ }^{*}$ and K. Svennersten-Sjaunja* \\ *Swedish University of Agricultural Sciences, Department of Animal Nutrition and Management, SE-753 23 Uppsala, Sweden \\ †Swedish Dairy Association, SE-223 70 Lund, Sweden \\ ¥Swedish University of Agricultural Sciences, Department of Food Science, SE-750 07 Uppsala, Sweden
}

\section{ABSTRACT}

Automatic in-line measurement of milk composition and milk yield could be a useful tool in management of the dairy herd. Data on milk components and milk yield provide information on milk quality alterations and cow health status but are also useful in planning feeding and breeding. In automatic milking systems, udder quarters are milked individually, enabling analysis and recording at the udder-quarter level. Frequent records of components require knowledge about day-today variations. A component with greater day-to-day variation needs more frequent sampling when used as a diagnostic tool and for management decisions. Earlier studies have described the day-to-day variations in milk components for cow composite milk, but with the quarter milking technique and the possible sampling at the udder-quarter level, knowledge about day-to-day variations at the udder-quarter level is needed. In this study, udder-quarter and cow composite milk samples were collected from 42 consecutive milkings of 10 cows during $21 \mathrm{~d}$. Milk yield was recorded and the milk was analyzed for total protein, whey protein, casein, fat, lactose, and somatic cell count. The results showed that the day-to-day variations and mean values for 4 healthy udder quarters within a cow were similar. In addition, different milk components had different levels of day-to-day variation, the least variation being found in lactose $(0.9 \%)$ and the greatest in fat $(7.7 \%)$. This suggests that repeated milk sampling and analysis at the udder-quarter level can be used to detect alterations in composition and cow health and would, thus, be helpful in the management of the dairy herd.

Key words: dairy cow, milk composition, udder quarter, day-to-day variation

Received December 18, 2009.

Accepted May 2, 2010

${ }^{1}$ Corresponding author: Linda.Forsback@huv.slu.se

\section{INTRODUCTION}

Because the herd size in dairy production is growing, farmers need reliable tools for management of the cows. Recording of daily milk yield and analysis of different components in milk can be useful tools in the practical management of the dairy herd. Health disturbances, milk quality alterations, and parameters related to feeding strategy and reproduction are examples of factors that could be detected using daily milk records. Today, in-line analysis of milk parameters is used in automatic milking systems and parlor milking systems. Examples of parameters recorded today at the udderquarter level in automatic milking systems are record time, milk yield, milk flow, conductivity, and blood in milk. In addition, SCC is available at the cow composite level (DeLaval International AB, 2009).

In practice, knowledge about day-to-day variation is a prerequisite when deciding how often different parameters should be analyzed for different purposes and in determining the normal variation in each parameter, information needed in identifying disturbances. Day-today variations in milk composition have been described in several studies at the cow composite level (Gilbert et al., 1973; Syrstad, 1977; Čandek-Potokar et al., 2006; Quist et al., 2008) but not at the udder-quarter level. Hence, there is a need for knowledge about the day-today variations in milk components at the udder-quarter level.

The total outcome and quality of dairy products is highly dependent on the milk yield and content and quality of the components protein, fat, and lactose. Continuous measurement of these parameters gives information about deviations that could have an effect on raw milk quality. In addition, measuring milk composition and milk yield continuously can also be useful in herd management. Because the energy requirement of the dairy cow is highly dependent on milk yield, yield records are essential in calculating the daily ration for each cow. Changes in milk production can be a warning of health disturbances and incomplete milking (for a review, see Svennersten-Sjaunja et al., 1997). Fat content in milk could be an indicator of feeding and 
milking because it is highly dependent on the amount of fiber in the diet (Bauman and Griinari, 2003) and on udder emptying (Johansson et al., 1952; Nielsen et al., 2005; Tancin et al., 2007). Protein in milk is highly dependent on the genetic capacity of the cow but can be altered by factors such as stage of lactation and udder health (Auldist et al., 1996; Urech et al., 1999). Information on fat and protein levels is used for the planning of feeding strategies and in breeding. As described in many earlier studies, lactose decreases during mastitis (Linzell and Peaker, 1972; Kitchen, 1981; Berglund et al., 2007), and hence, measurements of lactose may be useful when evaluating udder health disturbances.

Milk SCC, which is an indicator of mastitis, is a parameter that can be recorded in cow composite milk in automatic milking systems. However, earlier studies have shown that individual quarters with udder health disturbances, and thereby impaired milk composition, can be masked in cow composite milk due to the dilution effect (Berglund et al., 2007; Forsbäck et al., 2009). Sampling and analysis of milk at the udder-quarter level should, therefore, be a more sensitive method for monitoring udder health and milk quality.

Relative day-to-day variation is the variation in a parameter that is not explained by any known variance component. Factors that contribute to day-to-day variation are random biological variation, errors in the analytical methods used, the sampling technique, and variation due to pathological and physiological changes. Čandek-Potokar et al. (2006) suggested that the major factor influencing variation in milk components is the random variation associated with various unexplained biological factors and other uncontrolled factors, i.e., the day-to-day variation. Consequently, knowledge about the day-to-day variation is critical when evaluating milk data for different purposes.

The aim of this investigation was to study day-to-day variations in milk composition and milk yield at udderquarter and cow composite levels in clinically healthy cows over a 3 -wk period and to describe the normal composition and variations in milk composition at the udder-quarter level and cow composite level.

\section{MATERIALS AND METHODS}

The study was performed at the Kungsängen Research Centre, Swedish University of Agricultural Sciences in Uppsala, Sweden. The study was approved by the Uppsala Ethical Committee.

\section{Animals}

The study involved 10 Swedish Red cows. One week before the experiment started, the cows were tested for
SCC at the cow composite level and bacteriologically for each quarter. All 10 cows met the preset criteria: SCC level $<100,000$ cells $/ \mathrm{mL}$ in cow composite milk and negative tests for bacteria in all 4 udder quarters. Despite all cows meeting the criteria before the experiment, early in the trial period, one cow (cow A) showed high SCC and bacteria (Enterobacter cloacae) in one udder quarter, which persisted during the whole trial. The remaining 9 cows were bacteriologically negative throughout the trial period. The mean lactation week and lactation number \pm standard deviation for all 10 cows were $27 \pm 2$ and $2.2 \pm 1.8$, respectively. When the trial started, the mean milk yield \pm standard deviation of the cows was $21.6 \pm 1.7 \mathrm{~kg} / \mathrm{d}$. The cows were kept in a stanchion barn and fed according to Swedish recommendations (Spörndly, 2003). They were milked twice daily with a milking interval of $9 \mathrm{~h}$ during daytime and $15 \mathrm{~h}$ during nighttime. All cows included in the study delivered milk to the dairy on the sampling occasions, and none of the cows were treated for mastitis.

\section{Milking Equipment and Milking}

Before the cows were milked, each teat was wiped with an udder towel and the first squirts of milk were rejected. The cows were milked with a special quarter milking machine (provided by DeLaval International AB, Tumba, Sweden) with monovac, pulsation ratio $70 / 30$, pulsation rate of 60 cycles/min, and system vacuum of $42 \mathrm{kPa}$. Each udder quarter was milked separately, and milking finished individually on each quarter when milk flow was approximately $300 \mathrm{~g} / \mathrm{min}$.

\section{Milk Sampling and Recording}

Udder-quarter and cow composite milk samples were collected during morning and evening milkings for 3 wk, i.e., for 42 milking occasions. During sampling all milk from the entire milking and each separate udder quarter was collected in special containers. Quarter milk and representative cow composite milk were sampled for analyses. Milk yield from each quarter was recorded. The following sampling routine was used: after gentle stirring, milk samples were collected from each quarter container, then all milk from separate quarters was mixed, and after gentle stirring, a cow composite sample was taken. The milk sampling tubes were prepared with $20 \%$ (wt/vol) bronopol, 2-bromo-2nitropropane-1,3-diol (VWR International AB, Stockholm, Sweden), which resulted in a concentration of $0.02 \%$ bronopol in the milk samples. Bacteriological milk samples were collected from all udder quarters of the cows directly after milking every morning during the experiment. Before this milk was collected in sterile 
tubes, the teats were wiped with an udder towel, the first squirts of milk were rejected, and the teats were disinfected with $70 \%$ alcohol and allowed to dry.

\section{Milk Analyses}

The milk samples were analyzed for SCC using electronic fluorescence-based cell counting (Fossomatic 5000, A/S N. Foss Electric, Hillerød, Denmark). Before measurement of SCC, the instrument was controlled with 2 different reference milk samples (Eurofins Steins Laboratorium A/S, Holstebro, Denmark) containing different levels of SCC. For milk composition (i.e., fat, total protein, lactose, and whey protein), the mid-infrared spectroscopy method (Fourier Transform Instrument, FT 120, Foss Electric) was used. Control of the instrument was performed before measurement with 3 different reference milk samples (Eurofins Steins Laboratorium A/S) with different compositions. The proportion of casein was calculated from the proportions of whey protein and total protein, using a rennet casein method described by Forsbäck et al. (2009). Bacteriological analysis of the milk samples was performed by The National Veterinary Institute, Uppsala, Sweden, according to quality assurance protocol SS-EN ISO/IEC 17025.

\section{Statistical Analyses}

Mean, standard deviation, and coefficient of variation for milk composition and milk yield in udder-quarter milk were calculated with the GLM and VARCOMP procedure in SAS 9.1 (SAS Institute, 2004) using the following model:

$$
\mathrm{Y}_{\mathrm{ijkl}}=\mu+\alpha_{\mathrm{i}}+(\alpha \beta)_{\mathrm{ij}}+(\alpha \gamma)_{\mathrm{ik}}+\mathrm{e}_{\mathrm{ijkl}},
$$

where $\mathrm{Y}_{\mathrm{ijkl}}=$ the ijklth observation of each trait; $\mu$ $=$ general mean; $\alpha_{i}=$ the effect of the ith cow; $(\alpha \beta)$ ${ }_{\mathrm{ij}}=$ the effect of the jth udder quarter within cow; $(\alpha \gamma)_{\mathrm{ik}}=$ the effect of the kth week within cow; and $\mathrm{e}_{\mathrm{ijkl}}$ $=$ random error.

Mean, standard deviation, and coefficient of variation for milk composition and milk yield in cow composite milk were calculated with the GLM and VARCOMP procedure in SAS using the following model:

$$
\mathrm{Y}_{\mathrm{ijk}}=\mu+\alpha_{\mathrm{i}}+(\alpha \beta)_{\mathrm{ij}}+\mathrm{e}_{\mathrm{ijk}} \text {, }
$$

where $Y_{\mathrm{ijk}}=$ the ijkth observation of each trait; $\mu=$ general mean; $\alpha_{i}=$ the effect of the ith cow; $(\alpha \beta)_{i j}=$ the effect of the jth week within cow; and $e_{i j k}=$ random error.
Mean and coefficient of variation of each udder quarter for milk composition and milk yield were calculated with the GLM and VARCOMP procedure in SAS using the following model:

$$
\mathrm{Y}_{\mathrm{ijk}}=\mu+\alpha_{\mathrm{i}}+\beta_{\mathrm{j}}+\mathrm{e}_{\mathrm{ijk}},
$$

where $Y_{\mathrm{ijk}}=$ the ijkth observation of each trait; $\mu=$ general mean; $\alpha_{\mathrm{i}}=$ the effect of the ith milking; $\beta_{\mathrm{j}}=$ the effect of the jth week; and $\mathrm{e}_{\mathrm{ijk}}=$ random error.

Coefficient of variation for random error, designated as day-to-day variation, was calculated from the means of each parameter and the standard deviation of the random error. Daily milk yield was determined as the sum of morning and evening milkings, and the daily milk composition was determined as the weighted average of morning and evening milkings. Logarithmic values of SCC were used for all statistical analyses.

\section{RESULTS}

\section{Udder-Quarter Level}

Mean values, standard deviation, and day-to-day variations in milk composition and milk yield in udderquarter samples for all 10 cows and for 9 cows (cow A excluded) are presented in Table 1. The least day-to-day variation at the udder-quarter level in daily production was found in lactose content $(0.9 \%)$ and the greatest in fat content $(7.7 \%)$. The day-to-day variation in daily production of total protein, casein, and whey protein content was found to be 1.4 to $1.8 \%$. Milk yield and SCC had a day-to-day variation of 7.0 and $2.0 \%$, respectively. There were small differences in mean values between the results for 10 and 9 cows. However, the day-to-day variation was greater when all 10 cows were included in the statistical calculation than when only 9 cows were included.

\section{Cow Composite Level}

Mean values, standard deviation, and day-to-day variations for milk composition and milk yield in cow composite milk samples for all 10 cows and for 9 cows (cow A excluded) are presented in Table 2. The greatest day-to-day variation in cow composite milk for daily production was in fat content $(7.2 \%)$ and the least in lactose content $(0.9 \%)$. The day-to-day variation for daily production in cow composite milk was similar to udder-quarter milk for all parameters except milk yield, which had a variation of $5.7 \%$ in cow composite milk. As seen in the udder-quarter milk, there were small differences in mean values and standard deviation between all 10 cows and 9 cows. When cow A was 
Table 1. Milk composition and milk yield for udder-quarter milk samples ${ }^{1}$

\begin{tabular}{|c|c|c|c|c|c|}
\hline Item & Sample & \multicolumn{2}{|c|}{$\mathrm{n}=9$} & \multicolumn{2}{|c|}{$\mathrm{n}=10$} \\
\hline \multirow[t]{2}{*}{ Total protein $(\%)$} & Morning & $3.41 \pm 0.25$ & 1.7 & $3.42 \pm 0.25$ & 2.6 \\
\hline & Daily & $3.47 \pm 0.24$ & 1.4 & $3.47 \pm 0.24$ & 2.0 \\
\hline \multirow[t]{2}{*}{ Whey protein (\%) } & Morning & $0.92 \pm 0.09$ & 2.0 & $0.92 \pm 0.11$ & 6.3 \\
\hline & Evening & $0.96 \pm 0.09$ & 2.4 & $0.96 \pm 0.15$ & 11.8 \\
\hline \multirow{2}{*}{ Casein (\%) } & Evening & $2.59 \pm 0.18$ & 2.3 & $2.60 \pm 0.19$ & 4.1 \\
\hline & Daily & $2.53 \pm 0.18$ & 1.8 & $2.53 \pm 0.17$ & 2.0 \\
\hline \multirow[t]{3}{*}{ Lactose (\%) } & Morning & $4.75 \pm 0.19$ & 1.0 & $4.72 \pm 0.22$ & 1.6 \\
\hline & Evening & $4.70 \pm 0.21$ & 1.0 & $4.68 \pm 0.23$ & 1.7 \\
\hline & Daily & $4.73 \pm 0.19$ & 0.9 & $4.70 \pm 0.22$ & 1.5 \\
\hline \multirow[t]{2}{*}{ Fat (\%) } & Morning & $3.77 \pm 0.73$ & 12.5 & $3.75 \pm 0.74$ & 13.8 \\
\hline & Evening & $5.76 \pm 1.04$ & 9.8 & $5.69 \pm 1.03$ & 10.1 \\
\hline \multirow{2}{*}{ Milk yield (kg) } & Evening & $2.16 \pm 0.54$ & 13.6 & $2.19 \pm 0.55$ & 14.9 \\
\hline & Daily & $5.78 \pm 1.14$ & 7.0 & $5.84 \pm 1.13$ & 7.5 \\
\hline
\end{tabular}

${ }^{1}$ Results are presented as mean value $\pm \mathrm{SD}$ and day-to-day variation $(\mathrm{CV})$ divided into morning and afternoon milkings, and daily production. The results are divided into 2 sets: one with 9 healthy cows included $(\mathrm{n}=9)$ and one with a cow with subclinical mastitis included in addition to the 9 healthy cows $(\mathrm{n}=10)$.

${ }^{2}$ Logarithmic values of SCC.

excluded from the material, all parameters showed less day-to-day variation compared with when all 10 cows were included.

\section{Within-Cow Comparisons}

Tables 3 and 4 show the minimum and maximum mean values and day-to-day variations within cows at the udder-quarter level for total protein, casein, whey protein, lactose, and SCC. In terms of mean values, there were individual levels for each cow, and at least for the healthy cows, there were generally small differences between udder quarters within cows. In cows $\mathrm{B}, \mathrm{E}$, and $\mathrm{G}$, there were some differences between the udder quarters in mean values of lactose and SCC, but the difference was not as great as in cow A. There were small differences in day-to-day variations between the udder quarters in the healthy cows for the analyzed parameters. The overall least day-to-day variation was found in lactose content in all cows. The day-to-day variation showed much greater maximum values for cow A than for any of the other cows. The greatest overall day-to-day variation was found in the udder quarter with high SCC in cow A. Interestingly, cow C showed a relatively high mean value of SCC among the healthy cows but the least day-to-day variation in that parameter.
Figure 1 shows the lactose and fat levels for every day during the test period for each udder quarter in 2 cows, A and I. Cow A, which had a high SCC in the left rear udder quarter, had greater and more stable levels of lactose in the 3 healthy udder quarters. The lactose level in the udder quarter with high SCC exhibited greater fluctuations and lesser contents. The 4 udder quarters in healthy cow I had similar levels of lactose and small fluctuations during the test period. The fat content during the test period showed high variation in all quarters of both cows, independent of the high SCC in one quarter of cow A.

\section{DISCUSSION}

This study, which included 9 clinically healthy and bacteriologically negative cows, describes the normal milk composition and yield at udder-quarter and cow composite levels from 42 consecutive milkings. The main findings in the study were that day-to-day variations in milk composition and milk yield of udder quarters within healthy cows are similar and that day-to-day variation differs among different milk components. For practical farming, this means that repeated measurements of milk composition at the udder-quarter level are useful in early detection of quality alterations and health disturbances. Using the cow as its own control 
Table 2. Milk composition and milk yield for cow composite milk samples ${ }^{1}$

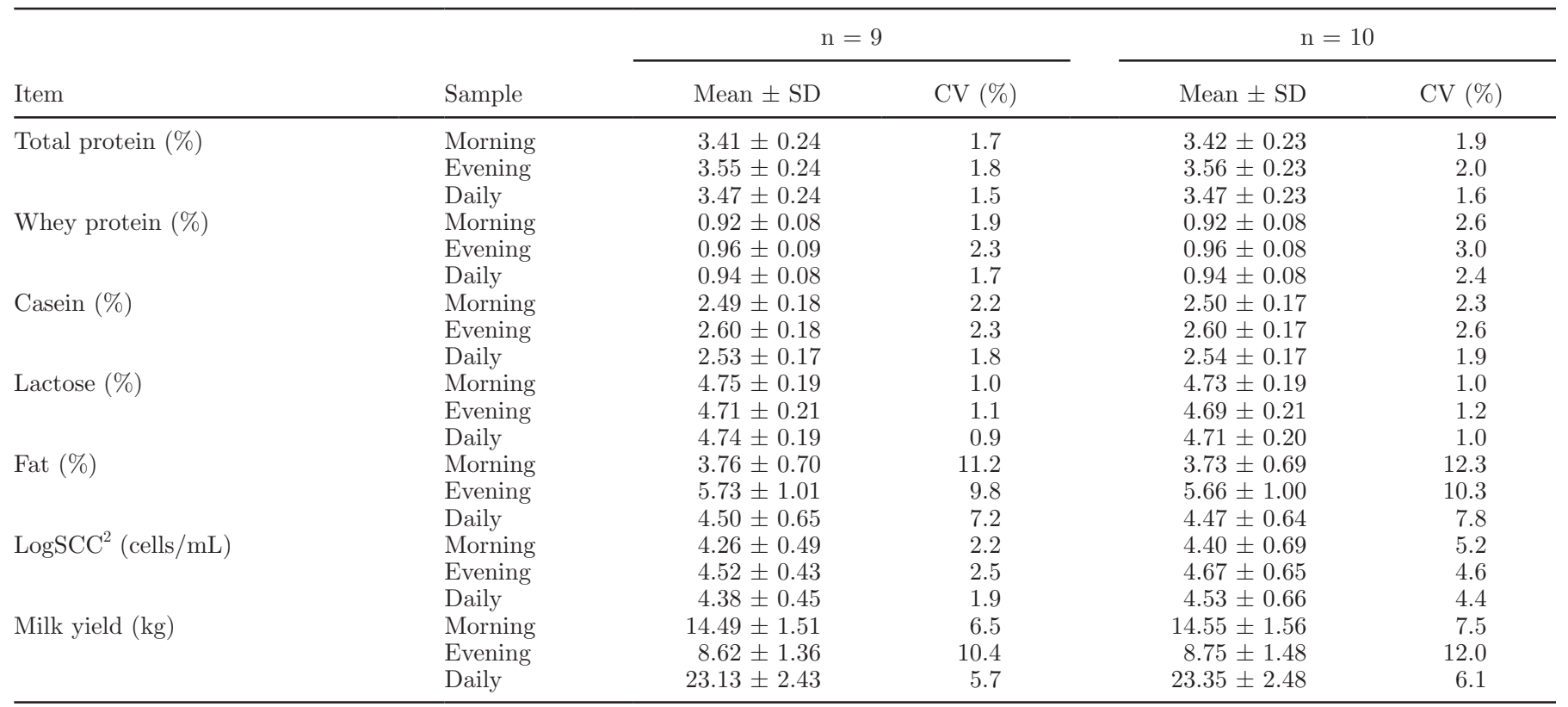

${ }^{1}$ Results are presented as mean value $\pm \mathrm{SD}$ and day-to-day variation $(\mathrm{CV})$ divided into morning and afternoon milkings, and daily production. The results are divided into 2 sets: one with 9 healthy cows included $(\mathrm{n}=9)$ and one with a cow with subclinical mastitis included in addition to the 9 healthy cows $(\mathrm{n}=10)$.

${ }^{2}$ Logarithmic values of SCC.

and monitoring each udder quarter might be a better method of evaluation than using a cut-off value for all cows. Because subclinical mastitis, followed by composition alterations, often occurs in one udder quarter (Kitchen, 1981; Munro et al., 1984; Barkema et al., 1997), within-udder comparisons are very useful. Many factors such as feeding, genetic capacity, lactation number, and lactation stage affect the composition of milk in each cow, and consequently each cow has its own level. Using cut-off values could then be misleading. Hence, repeated measurements at the udder-quarter level give better information on alterations in milk composition and health status than occasional measurements.
Lactose has the major osmotic regulatory function in milk (Ling et al., 1961) and is thus a very stable component of milk. Lactose is affected by mastitis, clinical as well as subclinical (Kitchen, 1981; Munro et al., 1984; Berglund et al., 2007), and hence, udder health disturbances are a source of variation in lactose. In our material, the day-to-day variation on a daily basis in udder-quarter milk in healthy animals was $0.9 \%$ for lactose, which was the overall least variation. According to Čandek-Potokar et al. (2006), the random variation over 2 consecutive days for lactose in cow composite milk was less, an estimated $0.3 \%$. When the subclinically infected cow in the present study was included

Table 3. Mean values of total protein, casein, whey protein, lactose, and SCC for individual udder quarters within cows $^{1}$

\begin{tabular}{lccccc}
\hline Cow & Total protein $(\%)$ & Casein $(\%)$ & Whey protein $(\%)$ & Lactose $(\%)$ & LogSCC $^{2}(\mathrm{cells} / \mathrm{mL})$ \\
\hline A & $3.46-3.76$ & $2.50-2.62$ & $0.86-1.25$ & $4.13-4.61$ & $4.34-6.44$ \\
B & $3.81-3.92$ & $2.80-2.89$ & $1.01-1.04$ & $4.61-4.72$ & $4.16-4.93$ \\
C & $3.60-3.68$ & $2.59-2.63$ & $1.01-1.05$ & $4.39-4.47$ & $4.86-4.99$ \\
D & $3.28-3.30$ & $2.39-2.42$ & $0.88-0.89$ & $4.93-4.95$ & $3.63-3.77$ \\
E & $3.34-3.38$ & $2.42-2.44$ & $0.92-0.95$ & $4.43-4.61$ & $4.64-4.98$ \\
F & $3.42-3.46$ & $2.59-2.62$ & $0.83-0.85$ & $4.91-4.95$ & $3.72-4.02$ \\
G & $3.25-3.29$ & $2.33-2.40$ & $0.89-0.94$ & $4.69-4.77$ & $4.03-5.37$ \\
H & $3.63-3.69$ & $2.63-2.68$ & $1.00-1.04$ & $4.68-4.72$ & $3.91-4.55$ \\
I & $3.61-3.65$ & $2.60-2.66$ & $0.98-1.02$ & $4.59-4.65$ & $4.67-4.80$ \\
J & $3.14-3.18$ & $2.32-2.35$ & $0.81-0.83$ & $4.94-4.97$ & $3.97-4.03$ \\
\hline
\end{tabular}

${ }^{1}$ Results are presented as minimum and maximum mean values for the 4 udder quarters of each cow.

${ }^{2}$ Logarithmic values of SCC. 
Table 4. Day-to-day variation (\%) in total protein, casein, whey protein, lactose, and SCC for individual udder quarters within cows $^{1}$

\begin{tabular}{lccccc}
\hline Cow & Total protein & Casein & Whey protein & Lactose & LogSCC $^{2}$ \\
\hline A & $2.8-8.7$ & $3.1-15.5$ & $3.2-43.1$ & $1.2-8.6$ & $3.3-9.9$ \\
B & $1.8-2.2$ & $2.4-2.9$ & $2.3-3.1$ & $0.8-1.0$ & $1.4-2.2$ \\
C & $1.4-1.6$ & $1.6-2.1$ & $1.5-2.1$ & $0.6-0.9$ & $0.9-1.2$ \\
D & $1.7-1.9$ & $2.1-2.3$ & $1.9-2.2$ & $0.8-0.9$ & $2.4-3.1$ \\
E & $1.9-2.2$ & $2.0-2.4$ & $2.4-2.9$ & $1.2-1.6$ & $1.1-3.4$ \\
F & $1.3-1.5$ & $1.6-2.1$ & $2.2-2.5$ & $1.2-1.3$ & $2.9-5.1$ \\
G & $1.3-1.6$ & $1.6-2.2$ & $1.3-2.5$ & $0.7-1.0$ & $2.4-4.0$ \\
H & $1.9-2.2$ & $2.4-2.8$ & $1.9-2.4$ & $0.9-1.0$ & $2.7-3.9$ \\
I & $1.7-1.9$ & $2.3-2.6$ & $1.8-2.4$ & $1.0-1.1$ & $1.3-1.7$ \\
J & $1.9-2.2$ & $2.0-2.6$ & $2.7-2.9$ & $1.1-1.3$ & $1.9-2.5$ \\
\hline
\end{tabular}

${ }^{1}$ Results are presented as minimum and maximum CV for random error for the 4 udder quarters of each cow.

${ }^{2}$ Logarithmic values of SCC.

in the statistical analysis, the day-to-day variation in lactose in udder-quarter milk increased. This indicates a greater variation in lactose content at the udderquarter level due to subclinical mastitis.

Protein content in milk is determined to a great extent by the genetic capacity of the cow. However, other sources of variation in protein include stage of lactation and mastitis (Auldist et al., 1996; Urech et al., 1999). In this study we found that the day-to-day variations in total protein, whey protein, and casein on a daily basis in udder-quarter milk samples were similar, 1.4, 1.8 , and $1.8 \%$, respectively. The cow composite milk samples showed similar levels of day-to-day variation to the quarter milk samples. Earlier studies have investigated the day-to-day variation in total protein in cow composite milk and found it to be about $1.6 \%$ (Svennersten-Sjaunja et al., 2005) or $2.1 \%$ calculated by Syrstad (1977), which is in line with our results. Candek-Potokar et al. (2006) predicted the random variation in protein levels over 2 consecutive days to be about $0.4 \%$.

The fat content of milk is highly dependent on udder emptying during milking because fat content is greater in residual milk and, thus, increases during milking (Johansson et al., 1952; Nielsen et al., 2005; Tancin et al., 2007). In the present study, this source of variation was reduced because quarter milking machines were used and the take-off milk flow for each udder quarter was $300 \mathrm{~g} / \mathrm{min}$. However, other factors such as the degree of udder filling and feeding also contribute to the level of fat in milk (Weiss et al., 2002; Bauman and Griinari, 2003). The day-to-day variation on a daily basis in fat content was $7.2 \%$ in cow composite milk and $7.7 \%$ in udder-quarter milk, making it the parameter with the greatest day-to-day variation in the present study. Calculations by Syrstad (1977) showed a day-to-day variation on a daily basis of $8.9 \%$ in fat at the cow composite level. In our study we found a greater day-to-day variation in morning milk compared with evening milk in quarter milk and in cow composite milk, which is in agreement with Lee and Wardrop (1984) and calculations by Syrstad (1977). The variation in fat due to unequal milking interval can be explained by the difference in residual milk carryover between consecutive milkings. Because the residual milk is related to total milk production and the result of milk ejection, the amount of residual milk is not constant for individual cows (Hamann and Dodd, 1992).

The day-to-day variation for daily production in milk yield for healthy cows was somewhat less in cow composite milk $(5.7 \%)$ than in udder-quarter milk (7.0\%). This greater variation might be explained by the greater amount of milk produced in rear udder quarters compared with front udder quarters. The dayto-day variation in milk yield at the cow composite level was comparable to figures calculated by Syrstad (1977) and data published by Svennersten-Sjaunja et al. (2005). The evening milkings showed greater dayto-day variations than did morning milkings. Lee and Wardrop (1984) found the residual milk yield variation (SD) to be twice as high for evening milkings compared with morning milkings. The greater variation in milk yield in evening milkings might be explained by the carryover of residual milk between consecutive milkings (Hamann and Dodd, 1992).

Because SCC forms part of the immune defense of the udder (Sordillo et al., 1997), the variation in SCC is highly dependent on the immune status of the cow. In addition, factors such as stress, stage of lactation, and age affect the SCC of the cow (Dohoo and Meek, 1982). During mastitis there is often a cyclical pattern of bacteria count and SCC (Daley et al., 1991), and therefore, the variation in SCC ought to be greater in the case of mastitis. In this study, the day-to-day variation in SCC was estimated to be approximately $2 \%$ in cow composite and udder-quarter milk for healthy cows. Chagunda 

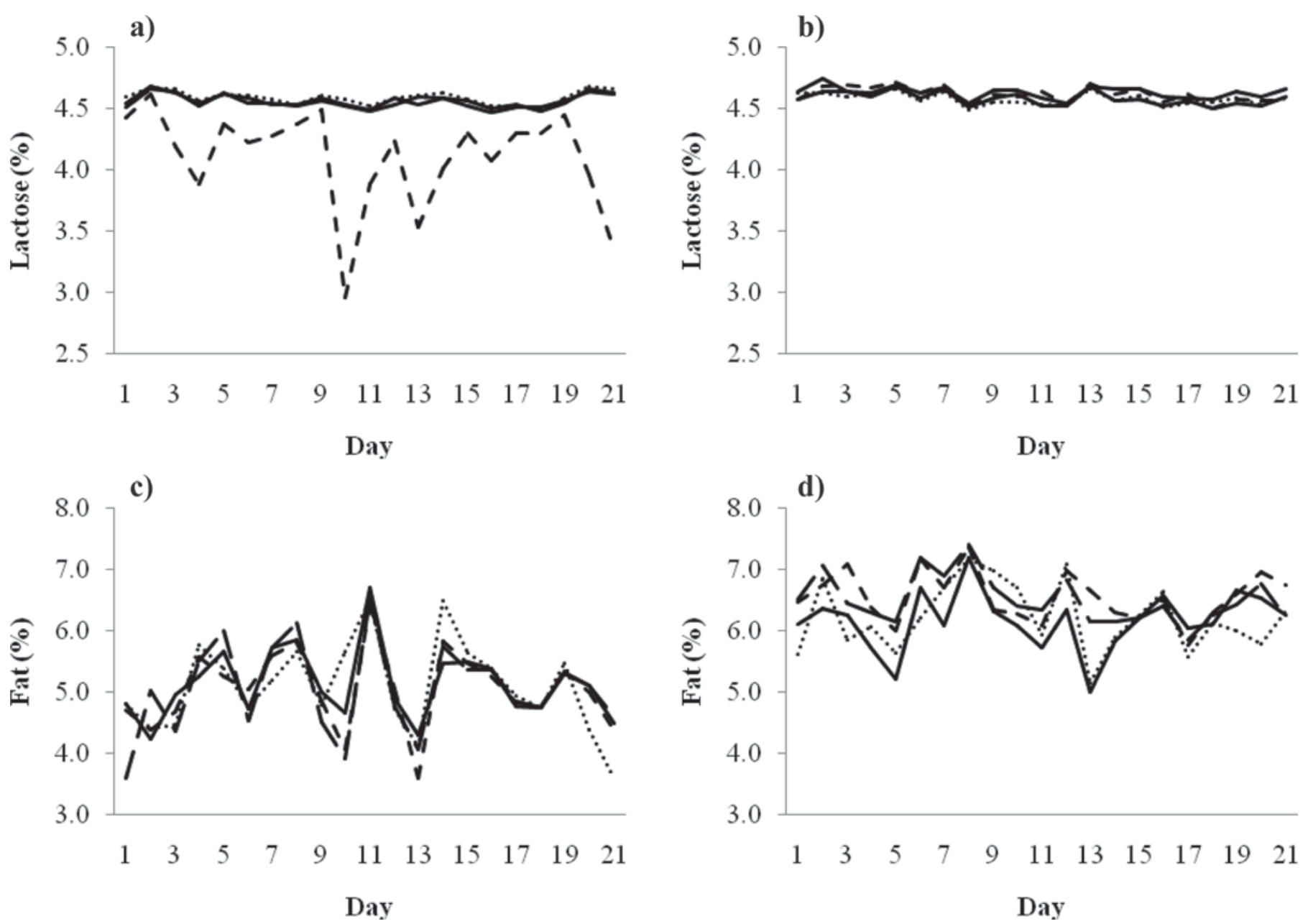

Figure 1. Concentration of lactose in all udder quarters of (a) cow A (which had subclinical mastitis in one udder quarter) and (b) cow I (all quarters tested bacteriologically negative during the trial period) at evening milking for the whole test period. Concentration of fat in all udder quarters of (c) cow A (which had subclinical mastitis in one udder quarter) and (d) cow I (all quarters tested bacteriologically negative during the trial period) at evening milking for the whole test period. Right rear quarter illustrated with solid line, right front with long dashed line, left rear with short dashed line, and left front with dotted line.

et al. (2006) found the overall coefficient of variation for SCC to be $4.7 \%$ in healthy cows and $11.4 \%$ in clinically mastitic cows, which indicates that mastitis increases the variation in SCC. However, that study included a greater number of samples from 3 different breeds, and the coefficient of variation presented was the overall variation. Because high SCC or mastitis was not included in the statistical model used in the present study, the variation caused by this was incorporated into the day-to-day variation. The variation in SCC in this study when all cows were included, i.e., 9 healthy cows and one cow with subclinical mastitis, was about $3 \%$. The increased day-to-day variation when the subclinically infected cow was included showed that some variance component not included in the model, probably the subclinical udder quarter, contributed to the day-to-day variation. A study by Cullen (1967) found that the variation in SCC was numerically greater in those udder quarters with high SCC. This implies that cows with udder disturbances might show greater dayto-day variation in the affected udder quarter.

The maximum and minimum mean values for the 4 udder quarters of each cow show that there are some differences between cows, which could be a consequence of factors such as genetic capacity, stage of lactation, and lactation number. However, at least in the healthy cows, the mean values and day-to-day variation in the 4 udder quarters showed the same pattern. This has been reported previously by Linzell and Peaker (1972), who found that milk composition in healthy cows showed small variations and the variations were similar between udder quarters. They also found greater variations, in addition to altered mean values, in udder quarters with clinical mastitis. This phenomenon was also observed in the present study in the only subclinically infected cow, which had a greater variation in the subclinically 
infected udder quarter than in the other 3 healthy udder quarters. For both mean values and day-to-day variation, each cow seemed to have its own individual level, which implies that milk composition should be equal within the udder.

Cow C, which was in lactation number 7 , showed high mean values of SCC at the udder-quarter level among the healthy cows but the least day-to-day variation and similar variations for all 4 udder quarters in that parameter. It has been reported by Schepers et al. (1997) that SCC increases more at the end of lactation in cows with lactation number $>1$, which might explain the somewhat high, but stable, SCC in cow C. Therefore, the greater level of SCC in this cow does not necessarily indicate udder health disturbances. This was further confirmed by the fact that all quarters showed the same pattern, because it is very seldom that all quarters in a cow udder are infected (Barkema et al., 1997). The day-to-day variation in milk components in combination with the mean value could provide better information on the component measured. Differing levels of mean values and variations in separate udder quarters within cows for milk composition and yield might be a sign of udder health disturbances.

Milk components with high day-to-day variation need to be sampled more frequently to obtain reliable results (Svennersten-Sjaunja et al., 1997). In the present study, lactose showed the least day-to-day variation and fat the greatest. For practical purposes, this means that fat needs more frequent sampling than lactose to get good results. Automatic measurement of milk components during milking is of interest when improving management of the dairy herd. As it seems that each cow has its own profile, it could be useful to use frequent measurements of various parameters for detection of disturbances in milk. Sampling at the udder-quarter level seems to be beneficial, especially when evaluating udder health disturbances.

\section{CONCLUSIONS}

From this study, it could be concluded that the day-today variations in the 4 udder quarters within a healthy cow are similar. Therefore, repeated measurements of milk composition at the udder-quarter level are suggested as a better method for detecting alterations in composition and health than the use of cut-off values from occasional measurements. The least day-to-day variation for healthy animals was found in lactose.

\section{ACKNOWLEDGMENTS}

The study was financially supported by the Swedish Research Council for Environment, Agricultural Sciences and Spatial Planning (FORMAS; Stockholm,
Sweden), strategic money from the Faculty of Veterinary Medicine and Animal Science (Uppsala, Sweden), and the Swedish Farmers' Foundation for Agricultural Research (SLF; Stockholm, Sweden). The authors thank Lars-Ove Sjaunja (Miris AB, Uppsala, Sweden) and Dietrich von Rosen (Department of Energy and Technology, Uppsala, Sweden) for statistical assistance and DeLaval International (Tumba, Sweden) for for providing the milking machines.

\section{REFERENCES}

Auldist, M. J., S. Coats, B. J. Sutherland, J. J. Mayes, G. H. McDowell, and G. L. Rogers. 1996. Effects of somatic cell count and stage of lactation on raw milk composition and the yield and quality of Cheddar cheese. J. Dairy Res. 63:269-280.

Barkema, H. W., Y. H. Schukken, T. J. G. M. Lam, D. T. Galligan, M. L. Beiboer, and A. Brand. 1997. Estimation of interdependence among quarters of the bovine udder with subclinical mastitis and implications for analysis. J. Dairy Sci. 80:1592-1599.

Bauman, D. E., and M. Griinari. 2003. Nutritional regulation of milk fat synthesis. Annu. Rev. Nutr. 23:203-227.

Berglund, I., G. Petterson, K. Östensson, and K. Svennersten-Sjaunja. 2007. Quarter milking for improved detection of increased SCC. Reprod. Domest. Anim. 42:427-432.

Čandek-Potokar, M., M. Prevolnik, D. Babnik, and T. Perpar. 2006. The uncertainty of results when estimating daily milk records. Anim. Res. 55:521-532.

Chagunda, M. G. G., T. Larsen, M. Bjerring, and K. L. Ingvartsen. 2006. L-lactate dehydrogenase and N-acetyl- $\beta$-D-glucosaminidase activities in bovine milk as indicators of non-specific mastitis. J. Dairy Res. 73:431-440.

Cullen, G. A. 1967. Short term variations in the cell count of cow's milk. Vet. Rec. 80:649-653.

Daley, M. J., E. R. Oldham, T. J. Williams, and P. A. Coyle. 1991. Quantitative and qualitative properties of host polymorphonuclear cells during experimentally induced Staphylococcus aureus mastitis in cows. Am. J. Vet. Res. 52:474-479.

DeLaval International AB. 2009. Automatic milking. http://www. delaval.com/Products/Automatic-Milking-Robotic-milking/ default.htm Accessed Dec. 14, 2009.

Dohoo, I. R., and A. H. Meek. 1982. Somatic cell counts in bovine milk. Can. Vet. J. 23:119-125.

Forsbäck, L., H. Lindmark-Månsson, A. Andrén, M. Åkerstedt, and K. Svennersten-Sjaunja. 2009. Udder quarter milk composition at different levels of somatic cell count in cow composite milk. Animal 3:710-717.

Gilbert, G. R., G. L. Hargrove, and M. Kroger. 1973. Diurnal variations in milk yield, fat yield, milk fat percentage, and milk protein percentage of Holstein-Friesian cows. J. Dairy Sci. 56:409-410.

Hamann, J., and F. H. Dodd. 1992. Machine milking and lactation. Pages 69-96 in Milking Routines. A. J. Bramley, F. H. Dodd, G. A. Mein, and J. A. Bramley, ed. Insight Books, Burlington, VT.

Johansson, I., N. Korkman, and N. J. Nelson. 1952. Studies on udder evacuation in dairy cows. Acta Agric. Scand. 2:43-81.

Kitchen, B. J. 1981. Review of the progress of dairy science: Bovine mastitis: Milk compositional changes and related diagnostic tests. J. Dairy Res. 48:167-188.

Lee, A. J., and J. Wardrop. 1984. Predicting daily milk yield, fat percent, and protein percent from morning or afternoon tests. J. Dairy Sci. 67:351-360.

Ling, E. R., S. K. Kon, and J. W. G. Porter. 1961. The composition of milk and the nutritive value of its components. Pages 195-263 in Milk: The Mammary Gland and Its Secretion. S. K. Kon and A. T. Cowie, ed. Academic Press Inc., London, UK.

Linzell, J. L., and M. Peaker. 1972. Day-to-day variations in milk composition in the goat and cow as a guide to the detection of subclinical mastitis. Br. Vet. J. 128:284-295. 
Munro, G. L., P. A. Grieve, and B. J. Kitchen. 1984. Effects of mastitis on milk yield, milk composition, processing properties and yield and quality of milk products. Aust. J. Dairy Technol. 39:7-16.

Nielsen, N. I., T. Larsen, M. Bjerring, and K. L. Ingvartsen. 2005. Quarter health, milking interval, and sampling time during milking affect the concentration of milk constituents. J. Dairy Sci. 88:3186-3200.

Quist, M. A., S. J. LeBlanc, K. J. Hand, D. Lazenby, F. Miglior, and D. F. Kelton. 2008. Milking-to-milking variability for milk yield, fat and protein percentage, and somatic cell count. J. Dairy Sci. 91:3412-3423.

SAS Institute. 2004. SAS/STAT ${ }^{\circledR} 9.1$ User's Guide. SAS Inst. Inc. Cary, NC.

Schepers, A. J., T. J. G. M. Lam, Y. H. Schukken, J. B. M. Wilmink, and W. J. A. Hanekamp. 1997. Estimation of variance components for somatic cell counts to determine thresholds for uninfected quarters. J. Dairy Sci. 80:1833-1840.

Sordillo, L. M., K. Shafer-Weaver, and D. DeRosa. 1997. Immunobiology of the mammary gland. J. Dairy Sci. 80:1851-1865.

Spörndly, R. 2003. Feed Tables for Ruminants 2003 (Fodertabeller för idisslare 2003). Dept. Anim. Nutr. Manag., SLU Swedish Univ. Agric. Sci., Uppsala, Sweden.
Svennersten-Sjaunja, K., U. Larsson, J. Bertilsson, and L. O. Sjaunja. 2005. The relative day-to-day variation in milk yield and composition for cows milked two or three times daily. Page 382 in 56th Ann. Mtg. Eur. Assoc. Anim. Prod., Uppsala, Sweden. Wageningen Academic Publishers, Wageningen, the Netherlands. Svennersten-Sjaunja, K., L. O. Sjaunja, J. Bertilsson, and H. Wiktorsson. 1997. Use of regular milking records versus daily records for nutrition and other kinds of management. Livest. Prod. Sci. 48:167-174.

Syrstad, O. 1977. Day-to-day variation in milk yield, fat content and protein content. Livest. Prod. Sci. 4:141-151.

Tancin, V., M. Uhrincat, L. Macuhova, and R. M. Bruckmaier. 2007. Effect of pre-stimulation on milk flow pattern and distribution of milk constituents at a quarter level. Czech J. Anim. Sci. 52:117121

Urech, E., Z. Puhan, and M. Schällibaum. 1999. Changes in milk protein fraction as affected by subclinical mastitis. J. Dairy Sci. $82: 2402-2411$

Weiss, D., M. Hilger, H. H. D. Meyer, and R. M. Bruckmaier. 2002. Variable milking intervals and milk composition. Milchwissenschaft $57: 246-249$. 